\title{
Effect of Duration of Seed Soaking before Sowing on Mungbean under Rainfed Conditions in the Southern Region of Bangladesh
}

\author{
M. A. RAZZAQUE ${ }^{1 *}$, S. RAFIQUZZAMAN ${ }^{2}$ AND M. N. ISLAM $^{3}$ \\ ${ }^{1}$ Agronomy Division, RARS, Bangladesh Agricultural Research Institute, Barisal, Bangladesh \\ ${ }^{2}$ Pulse Research Sub-station, Bangladesh Agricultural Research Institute, Madaripur, Bangladesh \\ ${ }^{3}$ Plant Pathology Division, Bangladesh Agricultural Research Institute, Gazipur, Bangladesh
}

Received 12 July 2004; received in revised form 26 July 2005; accepted 22 June 2006

\begin{abstract}
A field experiment was conducted at the farming system research and development site Lebukhali, Patuakhali of Bangladesh Agricultural Research Institute during 1999 and 2000 to study the effect of seed soaking duration before sowing on yield of two mungbean varieties BARImung-2 and BARImung-5. Seeds were soaked with fresh water for 0, 2, 4, 6 and 8 hours. The results revealed that plants produced with 4 hours soaking gave the maximum seed yield $(1379 \mathrm{~kg} / \mathrm{ha})$. BARlmung-5 produced higher yield (1457 kg/ha) than that of BARImung 2. Control (no soaking) gave lower yield. The highest benefit cost ratio (3.51) was obtained from 4 hours soaking.
\end{abstract}

Key words: Mungbean variety, time of seed soaking, yield.

\section{INTRODUCTION}

Mungbean (Vigna radiata (L.) Wilczek) is an important pulse crop in Bangladesh. The crop is grown well in the coastal regions of Bangladesh (Agroecological zone-13) during dry winter season under rainfed condition. Under rainfed condition, uncertainity of moisture availability at the time of sowing causes poor emergence, which directly affects crop establishment and grain yield (Ahmed and Sandhu,1989). Mungbean usually sown in this region at the end January to Mid February. The soils in this region are clay type which become compact and hard on drying (Choudhury et al., 2000). Farmer in this region do not pay much attention to the mungbean cultivation. They cultivate mungbean under rainfed conditions with minimum tillage. More over the growing season of this crop is characterized by minimum rainfall and high evaporative demand. Residual soil moisture is often depleted in the process of seedbed preparation, resulting in poor germination. Seed germination and stand establishment under deficit soil moisture depend largely on the seed size and tillage condition (Hadas, 1975). Wide variation in seed size among mungbean genotypes have been reported (Tickoo et al., 1988) and attempts are being made to introduce bold seeded varieties for enhancing yield (Hamid et al., 1994). For imbibition and germination bolder seeds require more water than smaller seeds. Stand establishment of bold seeded mungbean under deficit soil moisture conditions may thus pose serious problem. Seeds of BARImung-5 is bolder in size and its

\footnotetext{
* Corresponding author: SO, Agronomy Division, RARS, BARI, Rahmatpur, Barisal. Phone: 01715208814

(C) 2006, School of Agriculture and Rural Development, Bangladesh Open University. All rights reserved.
} 
seed coat is comparatively hard thanBARImung-2 (smaller size) which does not properly germinate with residual soil moisture in southern region of Bangladesh. Seed can be soaked before sowing to met the initial seed imbibition requirement. Khan et al. (1979) reported that seed soaking before sowing stimulate the emergence and seedling growth. This initial difference was maintained and resulted in higher grain yield. Thus the present study was undertaken to investigate weather the problem with soil moisture deficiency at sowing time can be mitigated by seed soaking before sowing under rainfed condition.

\section{MATERIALS AND METHODS}

A field experiment was conducted at the Farming System Research and Development Site Lebukhali, Patuakhali of Bangladesh Agricultural Research Institute during January to May in rabi season of 1999 and 2000. The soil belongs to silty clay of Barisal tidal clay series in the Ganges Tidal Floodplain region (AEZ-13) and of medium high land. Rainfall and temperature data were recorded daily in the experimental site and presented in Table 1. The experiment was laid out in a split plot design with 5 replications keeping seed soaking treatment such as 0 hour soaking (control), 2 hours soaking, 4 hours soaking, 6 hours soaking and 8 hours soaking in the main plots and varieties viz. BARImung- 2 and BARImung -5 in the sub plots. Care was taken to select uniform seed size of each variety and the mean seed size was 23 to $25 \mathrm{mg}$ and 38 to $40 \mathrm{mg}$ for BARImung2 and BARImung-5 respectively. Moisture of the experimental field was (8-12) \% at seed sowing. Seeds were sown continuously in a row with $30 \mathrm{~cm}$ distance between rows. The unit plots size was $6 \mathrm{~m} \times 5 \mathrm{~m}$. The seed rate of BARImung-5 was $50 \mathrm{~kg} / \mathrm{ha}$ and that of BARImung-2 was $30 \mathrm{~kg} / \mathrm{ha}$, because BARImung-5 is bolder than BARImung-2. Seeds were sown on $1^{\text {st }}$ February of both the years. The experiment plot was fertilized with NPK @ 20-10-20 kg/ha in the form of urea, TSP and MP. All fertilizers were applied as basal. Data on plant height, pods per plant, seeds per pod and 1000 seed weight recorded from 10 randomly selected plants in each treatment. For seed yield an area of $3 \mathrm{~m} \times 1 \mathrm{~m}$ was harvested from each plot.

Table 1. Weather report during the study at the experimental site (1999 and 2000)

\begin{tabular}{|c|c|c|c|c|c|c|c|}
\hline \multirow{3}{*}{ Month } & \multirow{3}{*}{$\begin{array}{l}\text { Period } \\
\text { (Days) }\end{array}$} & \multicolumn{4}{|c|}{ Temperature ${ }^{0} \mathrm{C}$} & \multirow{2}{*}{\multicolumn{2}{|c|}{ Rainfall (mm) }} \\
\hline & & \multicolumn{2}{|c|}{1999} & \multicolumn{2}{|c|}{2000} & & \\
\hline & & Maximum & Minimum & Maximum & Minimum & 1999 & 2000 \\
\hline \multirow{3}{*}{ January } & $1-10$ & 24.4 & 11.9 & 24.7 & 12.8 & 0 & 0 \\
\hline & $11-20$ & 27.6 & 14.0 & 25.3 & 10.9 & 0 & 0 \\
\hline & $21-31$ & 26.6 & 15.7 & 27.4 & 11.7 & 2 & 0 \\
\hline \multirow[t]{3}{*}{ February } & $1-10$ & 27.0 & 17.0 & 28.8 & 14.3 & 1 & 0 \\
\hline & $11-20$ & 26.2 & 15.3 & 31.1 & 14.5 & 4 & 0 \\
\hline & $21-29$ & 28.0 & 15.3 & 30.6 & 20.2 & 0 & 15 \\
\hline \multirow[t]{3}{*}{ March } & $1-10$ & 31.2 & 20.9 & 31.2 & 17.8 & 12 & 0 \\
\hline & $11-20$ & 31.9 & 21.6 & 34.6 & 19.7 & 1 & 0 \\
\hline & $21-31$ & 33.5 & 20.3 & 34.8 & 23.2 & 0 & 3 \\
\hline \multirow[t]{3}{*}{ April } & $1-10$ & 33.9 & 24.8 & 35.5 & 23.5 & 0 & 48 \\
\hline & $11-20$ & 33.8 & 23.1 & 34.0 & 24.1 & 64 & 12 \\
\hline & $21-30$ & 33.0 & 23.4 & 35.5 & 26.6 & 69 & 5 \\
\hline \multirow[t]{3}{*}{ May } & $1-10$ & 32.8 & 23.8 & 32.8 & 23.1 & 116 & 180 \\
\hline & $11-20$ & 34.8 & 26.6 & 32.5 & 24.8 & 13 & 84 \\
\hline & $21-31$ & 32.4 & 25.9 & 33.7 & 25.1 & 102 & 134 \\
\hline
\end{tabular}

Source: Meteorological department Agargaon, Dhaka

\section{RESULTS AND DISCUSSION}

\section{Effect of seed soaking}

Seed yield and other characteristics studied were significantly influenced by duration of soaking (Table 2). The highest seed yield $(1379 \mathrm{~kg} / \mathrm{ha})$ was obtained from the plants developed with 4 hours soaking. Higher yield obtained from 4 hours soaking was attribute to higher plant population, 
higher number of pods per plant and higher number of seeds per pod as discussed later. The rate of emergence and number of plants per $\mathrm{m}^{2}$ were higher with 4 hours soaking which could be due to the fact that the seeds absorbed sufficient water that enhanced seed germination. Perhaps the availability of seed moisture was better with 4 hours soaking and the seeds were able to imbibe water more quickly that enhanced germination process and resulted in faster emergence and higher plant establishment. This early emergence provide more time for growth and development of the plant which contributes to the yield. The soaked seed had already met part of its imbibitions requirement which stimulate early emergence though seeds are damaged with excess moisture. Emergence with 2 and 6 hours soaking was similar and yield was statistically similar. The lower yield obtained from 0 hour soaking (control) was due to low moisture for seed germination and emergence. The yield of the crop was gradually increased up to 4 hours soaking thereafter declined. It might be due to the fact that some seeds were damaged with excess moisture. The range of yield reduction was $8.95-47.08 \%$ compared to that with 4 hours seed soaking.

Table 2. Yield and yield components of Mungbean as affected by duration of seed soaking at Lebukhali, Patuakhali (Pooled value)

\begin{tabular}{c|c|c|c|c|c|c|c|c}
\hline $\begin{array}{c}\text { Time of } \\
\text { soaking }\end{array}$ & Emergence $/ \mathrm{m}^{2}$ & Plants $/ \mathrm{m}^{2}$ & $\begin{array}{c}\text { Plant } \\
\text { height } \\
(\mathrm{cm})\end{array}$ & $\begin{array}{c}\text { Pods/plant } \\
\text { (no.) }\end{array}$ & $\begin{array}{c}\text { Seeds/pod } \\
\text { (no.) }\end{array}$ & $\begin{array}{c}1000- \\
\text { seed } \\
\text { weight }(\mathrm{g})\end{array}$ & $\begin{array}{c}\text { Seed } \\
\text { yield } \\
(\mathrm{kg} / \mathrm{ha})\end{array}$ & $\begin{array}{c}\% \text { yield } \\
\text { reduction* }\end{array}$ \\
\hline \hline 0 Hours & $43.7 \mathrm{~d}$ & $30.30 \mathrm{e}$ & $40.70 \mathrm{c}$ & $9.46 \mathrm{c}$ & $8.75 \mathrm{c}$ & $30.78 \mathrm{c}$ & $730 \mathrm{e}$ & 47.08 \\
2 hours & $50.0 \mathrm{~b}$ & $37.75 \mathrm{~b}$ & $43.11 \mathrm{a}$ & $10.71 \mathrm{~b}$ & $9.58 \mathrm{~b}$ & $31.96 \mathrm{a}$ & $1256 \mathrm{~b}$ & 8.95 \\
4 hours & $57.4 \mathrm{a}$ & $39.25 \mathrm{a}$ & $43.07 \mathrm{a}$ & $11.22 \mathrm{a}$ & $9.91 \mathrm{a}$ & $31.94 \mathrm{a}$ & $1379 \mathrm{a}$ & - \\
6 hours & $49.6 \mathrm{~b}$ & $35.34 \mathrm{c}$ & $42.80 \mathrm{~b}$ & $10.76 \mathrm{~b}$ & $9.87 \mathrm{ab}$ & $31.42 \mathrm{~b}$ & $1156 \mathrm{c}$ & 16.17 \\
8 hours & $45.1 \mathrm{c}$ & $34.09 \mathrm{~cd}$ & $42.97 \mathrm{~b}$ & $10.55 \mathrm{~b}$ & $9.42 \mathrm{bc}$ & $31.33 \mathrm{~b}$ & $1052 \mathrm{~d}$ & 23.70 \\
\hline
\end{tabular}

Note: *Yield reduction over 4 hours soaking

Means in a column bearing the same letters do not differ significantly at $5 \%$ level of DMRT

\section{Effect of variety}

The varieties exerted significant influence on yield and yield contributing characters (Table 3). Average of two years data indicated that BARImung-5 produced higher yield ( $1457 \mathrm{~kg} / \mathrm{ha})$ than that of BARImung-2 (773 kg/ha). The higher yield obtained in BARImung-5 might be due to maximum number of pods per plant, higher number of seeds per pod and higher 1000- seed weight. The lower yield was recorded from BARImung-2 which might be due to less number of pods per plant, minimum seeds per pod and lower 1000-seed weight.

Table 3. Yield and yield components of Mungbean as affected by variety at Lebukhali Patuakhali (Pooled average of 1999 and 2000)

\begin{tabular}{l|c|c|c|c|c|c|c}
\hline Variety & Emergence $/ \mathrm{m}^{2}$ & Plants $/ \mathrm{m}^{2}$ & $\begin{array}{c}\text { Plant height } \\
\text { (cm) }\end{array}$ & $\begin{array}{c}\text { Pods/plant } \\
\text { (no.) }\end{array}$ & $\begin{array}{c}\text { Seeds/pod } \\
\text { (no.) }\end{array}$ & $\begin{array}{c}1000 \text { seed } \\
\text { weight }(\mathrm{g})\end{array}$ & $\begin{array}{c}\text { Seed yield } \\
\text { (kg/ha) }\end{array}$ \\
\hline \hline BARImung-2 & $48.04 \mathrm{~b}$ & $36.60 \mathrm{~b}$ & $41.73 \mathrm{~b}$ & $9.80 \mathrm{~b}$ & $9.27 \mathrm{~b}$ & $23.89 \mathrm{~b}$ & $773 \mathrm{~b}$ \\
BARImung-5 & $50.28 \mathrm{a}$ & $34.09 \mathrm{a}$ & $43.33 \mathrm{a}$ & $11.28 \mathrm{a}$ & $9.97 \mathrm{a}$ & $39.08 \mathrm{a}$ & $1457 \mathrm{a}$ \\
\hline
\end{tabular}

Note: Means in a column bearing the same letters do not differ significantly at $5 \%$ level of DMRT

\section{Interaction between soaking and varieties}

Seed yield and other attributes were significantly influenced by the interaction of seed soaking duration and varieties except seeds per pod. The highest seed $(1851 \mathrm{~kg} / \mathrm{ha})$ was produced by BARImung-5 when seed soaked for 4 hours before sowing. Higher seed yield of BARImung-5 compared to BARImung-2 was due to higher plants per square metre, higher pods per plant and higher seed weight. However seed yield is of BARImung- 5 was gradually reduced after 4 hours 
soaking (Table 4). Average of two years data indicated that soaking the seed before sowing increased the seedling emergence and finally yield per plot. Ahmed and Sandhu (1989) reported that wheat yield increased $10 \%$ due to soaking the seed for 12 hours before sowing. Khan et al. (1979) also reported that soaking the seeds before sowing stimulated emergence and seedling growth as a result higher grain yield in wheat. Padole (1979) however did not find any significant difference in grain yield between unsoaked and water soaked seeds in wheat. Rainfall is always uncertain in rainfed areas. Soaking the seed is preferable if available soil moisture is not sufficient in the upper soil layer for adequate stand establishment. Soaking the mungbean seed in water for 4 hours before sowing can help in establishing early uniform stand under limited soil moisture.

Table 4. Interaction of seed soaking and variety on yield attributes of mungbean

\begin{tabular}{c|c|c|c|c|c|c|c|c}
\hline $\begin{array}{c}\text { Soaking } \\
\text { time }\end{array}$ & Variety & Emergence $/ \mathrm{m}^{2}$ & Plants $/ \mathrm{m}^{2}$ & $\begin{array}{c}\text { Plant } \\
\text { height } \\
\text { (cm) }\end{array}$ & $\begin{array}{c}\text { Pods/plan } \\
\mathrm{t}(\mathrm{no} .)\end{array}$ & $\begin{array}{c}\text { Seeds/pod } \\
\text { (no.) }\end{array}$ & $\begin{array}{c}1000- \\
\text { seed } \\
\text { weight }(\mathrm{g})\end{array}$ & $\begin{array}{c}\text { Seed } \\
\text { yield } \\
\text { (kg/ha) }\end{array}$ \\
\hline \hline $\mathrm{T} 1$ & $\mathrm{~V} 1$ & $42.4 \mathrm{e}$ & $34.81 \mathrm{bc}$ & $39.01 \mathrm{c}$ & $8.86 \mathrm{e}$ & $8.76 \mathrm{~cd}$ & $23.73 \mathrm{c}$ & $630 \mathrm{f}$ \\
& $\mathrm{V} 2$ & $45.0 \mathrm{cde}$ & $25.8 \mathrm{~d}$ & $42.4 \mathrm{ab}$ & $10.07 \mathrm{~cd}$ & $8.71 \mathrm{~d}$ & $37.83 \mathrm{~b}$ & $831 \mathrm{de}$ \\
\hline $\mathrm{T} 2$ & $\mathrm{~V} 1$ & $47.8 \mathrm{bcde}$ & $38.69 \mathrm{a}$ & $41.28 \mathrm{bc}$ & $9.56 \mathrm{de}$ & $9.08 \mathrm{bcd}$ & $23.88 \mathrm{c}$ & $782 \mathrm{de}$ \\
& $\mathrm{V} 2$ & $52.2 \mathrm{ab}$ & $36.82 \mathrm{ab}$ & $44.94 \mathrm{a}$ & $11.87 \mathrm{~cd}$ & $10.08 \mathrm{a}$ & $40.04 \mathrm{a}$ & $1717 \mathrm{~b}$ \\
\hline $\mathrm{T} 3$ & $\mathrm{~V} 1$ & $56.8 \mathrm{a}$ & $39.3 \mathrm{a}$ & $42.70 \mathrm{ab}$ & $10.3 \mathrm{c}$ & $9.63 \mathrm{ab}$ & $24.23 \mathrm{c}$ & $898 \mathrm{~d}$ \\
& $\mathrm{~V} 2$ & $58.0 \mathrm{a}$ & $39.2 \mathrm{a}$ & $43.45 \mathrm{ab}$ & $12.10 \mathrm{a}$ & $10.2 \mathrm{a}$ & $39.65 \mathrm{a}$ & $1851 \mathrm{a}$ \\
\hline $\mathrm{T} 4$ & $\mathrm{~V} 1$ & $49.0 \mathrm{bcd}$ & $35.33 \mathrm{bc}$ & $42.45 \mathrm{ab}$ & $10.37 \mathrm{c}$ & $9.72 \mathrm{a}$ & $23.84 \mathrm{c}$ & $878 \mathrm{de}$ \\
& $\mathrm{V} 2$ & $50.0 \mathrm{bc}$ & $35.35 \mathrm{bc}$ & $43.15 \mathrm{ab}$ & $11.15 \mathrm{~b}$ & $10.02 \mathrm{a}$ & $39.0 \mathrm{a}$ & $1495 \mathrm{c}$ \\
\hline $\mathrm{T} 5$ & $\mathrm{~V} 1$ & $44.0 \mathrm{de}$ & $34.88 \mathrm{~b}$ & $43.24 \mathrm{ab}$ & $9.95 \mathrm{~cd}$ & $9.12 \mathrm{bc}$ & $23.77 \mathrm{c}$ & $727 \mathrm{ef}$ \\
& $\mathrm{V} 2$ & $46 \mathrm{cde}$ & $33.3 \mathrm{c}$ & $42.70 \mathrm{ab}$ & $11.15 \mathrm{~b}$ & $9.72 \mathrm{a}$ & $38.89 \mathrm{a}$ & $1370 \mathrm{c}$ \\
\hline
\end{tabular}

Note: Means in a column bearing the same letters do not differ significantly at $5 \%$ level of DMRT

$\mathrm{T} 1=$ No soaking, $\mathrm{T} 2=2$ Hours soaking, $\mathrm{T} 3=4$ hours soaking, $\mathrm{T} 4=6$ hours soaking, $\mathrm{T} 5=8$ hours soaking, V1= BARImung-2, V2= BARImung -5

Table 5. Economics of seed soaking in mungbean cultivation

\begin{tabular}{c|c|c|c|c|c}
\hline Treatment & Yield (kg/ha) & $\begin{array}{c}\text { Gross return } \\
\text { (Tk/ha) }\end{array}$ & $\begin{array}{c}\text { Cost of } \\
\text { cultivation } \\
\text { (Tk/ha) }\end{array}$ & $\begin{array}{c}\text { Gross margin } \\
\text { (Tk/ha) }\end{array}$ & $\begin{array}{c}\text { Benefit cost } \\
\text { ratio }\end{array}$ \\
\hline \hline T1V1 & 630 & 12600 & 9660 & 2940 & 1.30 \\
T1V2 & 831 & 16620 & 10460 & 6160 & 1.59 \\
T2V1 & 782 & 15640 & 9740 & 5900 & 1.60 \\
T2V2 & 1717 & 34340 & 10540 & 23800 & 3.26 \\
T3V1 & 898 & 17960 & 9740 & 8220 & 1.84 \\
T3V2 & 1851 & 37020 & 10540 & 26480 & 3.51 \\
T4V1 & 878 & 17560 & 9740 & 7820 & 1.80 \\
T4V2 & 1495 & 29900 & 10540 & 19360 & 2.84 \\
T5V1 & 727 & 14540 & 9740 & 4800 & 1.49 \\
T5V2 & 1370 & 27400 & 10540 & 16860 & 2.60 \\
\hline
\end{tabular}

Note: V1 =BARImung-2, V2= BARImung-5

$\mathrm{T} 1=$ No soaking, $\mathrm{T} 2=2$ hours soaking, $\mathrm{T} 3=4$ hours soaking, $\mathrm{T} 4=6$ hours soaking, $\quad \mathrm{T}=\mathrm{T} 5=8$ hours soaking
Input $\quad \mathrm{Tk} / \mathrm{kg}$

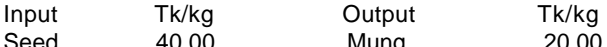

$\begin{array}{lrr}\text { Urea } & 7.00 \\ \text { TSP } & 15.00\end{array}$

MP $\quad 10.00$

Soaking $=$ Tk. 80.00 per manday (One manday per hectare required for seed soaking). 


\section{Cost and return analysis}

The highest gross return (37020 Tk/ha) was obtained from 4 hours soaking followed by 2 hours soaking (34340 Tk/ha) (Table 5). The lowest return was with 0 hour soaking (control). The maximum (3.51) and minimum (1.30) benefit cost ratio was obtained with 4 hours and 0 hour soaking respectively.

\section{CONCLUSION}

Based on the results of this study it is concluded that under Patuakhali (AEZ-13) condition the optimum time of seed soaking before sowing of mungbean was 4 hours and BARImung-5 produces higher yield compared to BARImung-2.

\section{LITERATURE CITED}

Ahmed, S. and Sandhu, G. R. 1989. Yield and yield components of wheat as influenced by seeding depth and seed pre soaking. Pakistan J AgricRes 10(1), 1-4.

Choudhury, D. A., Hamid, A., Hasem, A. and Miah. G. U. 2000. Mungbean seed germination under soil moisture regimes. Bangladesh J Agril Res 25(2), 375-377.

Hadas, A. 1975. Water transfer $t$ germinating seeds as affected by soil hudraulic properties and seed water contact impedance. In "Heat and Mass transfer in the Biosphere" (D. A. de Vries and N. A. Afgan, Eds.), Vol. 1, Transfer processes in the plant Environment. John wiley and Sons, New York.

Hamid, A., Hasem A., Miah. A. A. and Chanda, M. L. 1994. Genotypic variation in morphological and physiological characters and yield attributrs of Mungbean. Paper presented 6 April 1994 in International Symposium on Pulse research held in New Delhi, India.

Khan, R. A., Azeem, M., Lalah, R. A., and Ahmed, S. 1979. Crop management practice for dryland wheat. Pakistan J Agric Sci 26 (1-2), 7-12.

Padole, V. R. 1979. Effect of presoaking seed treatment of wheat seed with chemicals and hormones on yield and uptake of NPK. J Maharastra Agric Univ 4 (1), 85-88.

Tickoo, J. L., Ahn. C. S., Chen, H. K. and Shanmugasudaram, S. 1998. Utilization of the genetic variability from AVRDC mungbean germplasm 103-110. In "AVRDC mungbean : Proc.", 6 April 1994, Second International Symposium on Pulses Research held in New Delhi, India. 